\title{
Hypersensitivity reactions to biologics (part II): classifications and current diagnostic and treatment approaches
}

\author{
Askin Gülsen · Bettina Wedi · Uta Jappe
}

Received: 16 December 2019 / Accepted: 31 March 2020 / Published online: 19 June 2020

(C) The Author(s) 2020

\begin{abstract}
Purpose Biotechnological substances (BS) have rapidly expanded their clinical use. In parallel, there is an increase in expected or unexpected immunological or non-immunological adverse effects. In this part of the review, the current nomenclature of BSs, the classification of hypersensitivity reactions (HSR), as well as diagnostic and treatment approaches are documented to provide the tools to understand the nomenclature used throughout the databases and the need to harmonize it where applicable.

Methods Detailed searches were performed on Pubmed, Web of Science, and Google Scholar to include all available publications. The search terms, such as specific BS, allergy, anaphylaxis, hypersensitivity, reactions, classification, diagnosis, grading, management, and desensitization, were determined for the search. Case reports, articles, and reviews on this subject were included.

Results Today, a variety of non-standardized methods are used to support the clinical diagnosis. These include prick-to-prick tests and intradermal tests with the drug itself and its potentially allergenic ingredients. More rarely, anti-drug antibodies are detected
\end{abstract}

Part I see https://doi.org/10.1007/s40629-020-00126-6

A. Gülsen · Prof. Dr. U. Jappe, MD, MSc ( $\square)$

Division of Clinical and Molecular Allergology, Research

Center Borstel, Airway Research Center North (ARCN),

Member of the German Center for Lung Research (DZL), Parkallee 35, 23845 Borstel, Germany

Interdisciplinary Allergy Outpatient Clinic, Department of Pneumology, University of Luebeck, Luebeck, Germany ujappe@fz-borstel.de

B. Wedi

Department of Dermatology and Allergy, Comprehensive Allergy Centre, Hannover Medical School, 30625 Hannover, Germany and basophil activation tests are used by centers with research facilities. Although the treatment protocols for acute conditions vary, the overall approach is the same.

Conclusion HSRs to BS are gradually increasing with the widening of their clinical use and indications. It is very important to prevent HSRs and to know the degree of severity as well as the emergency treatment algorithm. This review summarizes the diagnostic tests that should be applied: (a) immediately during/after a reaction, and (b) subsequently, and in the case that a switch of BS is not possible, desensitization is an option.

Keywords Allergy · Anaphylaxis · Anti-drug antibodies · Biologicals · Desensitization

Abbreviations

ADA Anti-drug antibodies

ADR Adverse drug reaction

$\alpha$-Gal Galactose- $\alpha$-1,3-galactose

ARCN Airway Research Center North

BAT Basophil activation test

BMBF Federal Ministry for Science and Education

BS Biotechnological substances

BWH Brigham and Women's Hospital

CD Cluster of differentiation

CDR Complementarity-determining region

CRS Cytokine release syndrome

EGFR Epidermal growth factor receptor

ELISA Enzyme-linked immunosorbent assay

Erb Eukaryotic ribosome biogenesis protein

GM-CSF Granulocyte-macrophage colony-stimulating factor

HSR Hypersensitivity reaction

IFN Interferon

Ig Immunoglobulin 


$\begin{array}{ll}\text { IL } & \text { Interleukin } \\ \text { INN } & \text { International nonproprietary names } \\ \text { mAb } & \text { Monoclonal antibody } \\ \text { RDD } & \text { Rapid drug desensitization } \\ \text { SPT } & \text { Skin-prick test } \\ \text { TGF } & \text { Transforming growth factor } \\ \text { TNF- } \alpha & \text { Tumor necrosis factor } \alpha \\ \text { USAN } & \text { United States' adopted names }\end{array}$

\section{Introduction}

Biotechnological substances (BS) have rapidly expanded their clinical use since the years they were first defined. In parallel, there is an increase in expected and unexpected side effects and various adverse drug reactions (ADR) [1]. These reactions can be acute infusion reactions, anaphylaxis, hypersensitivity reactions (HSR), cytokine release syndrome due to intravenous injection, and local injection site reactions, HSRs and anaphylaxis due to subcutaneous administration.

Moreover, BSs are different from most drugs in that they do not contain prodrugs or small chemical compounds, but are produced to make them as similar to human proteins as possible. Unlike other drugs, they are not metabolized classically, but have functions like other proteins and can be digested from the gastrointestinal tract. Therefore, ADRs are also quite different. The adverse effects can be either immunological or non-immunological, as well as due to the excessive response of the immune system depending on the pharmacological properties of the drug [2].

In this part of the review, the current nomenclature of BSs, the classification of hypersensitivity reactions, as well as diagnostic and treatment approaches will be discussed.

\section{Material and methods}

Detailed searches were performed on Pubmed, Web of Science, and Google Scholar to include all available publications. The search terms, such as specific BS, allergy, anaphylaxis, hypersensitivity, reactions, classification, diagnosis, grading, management, and desensitization, were determined for the search. Case reports, articles, and reviews on this subject were retrieved.

\section{Classification of biotechnological substances}

Biologics include fully human and humanized monoclonal antibodies (mAb), chimeric (human + murine) antibodies, and recombinant fusion proteins that affect specific functions of the immune system. The three most common classes of biologics are mAbs, fusion proteins, and cytokines (Table 1).

Currently approved mAbs target immunoglobulin (Ig)-E antibodies, cell surface molecules, soluble mediators, cytokines, viral proteins, and tumor antigens.
Table 1 Classification of biotechnological substances ${ }^{a}$

\begin{tabular}{|c|c|}
\hline Group & Example substances/targets \\
\hline \multicolumn{2}{|l|}{ Monoclonal antibodies } \\
\hline Towards IgE antibodies & $\begin{array}{l}\text { Omalizumab, ligelizumab, quil- } \\
\text { izumab }\end{array}$ \\
\hline \multirow[t]{3}{*}{ Towards cell surface molecules } & Rituximab (anti-CD20) \\
\hline & Basiliximab (anti-IL-2 receptor) \\
\hline & Efalizumab (anti-LFA-1) \\
\hline \multirow[t]{3}{*}{$\begin{array}{l}\text { Towards soluble mediators and } \\
\text { cytokines }\end{array}$} & $\begin{array}{l}\text { Infliximab, adalimumab (an- } \\
\text { ti-TNF } \alpha \text { ) }\end{array}$ \\
\hline & Daclizumab (anti-IL-2 R alpha) \\
\hline & Lanadelumab (plasma kallikrein) \\
\hline \multirow[t]{2}{*}{ Towards tumor antigens } & Cetuximab (EGFR) \\
\hline & Trastuzumab (HER2/neu/ErbB2) \\
\hline \multicolumn{2}{|l|}{ Fusion proteins } \\
\hline Soluble receptors for cytokines & Etanercept (TNF $\alpha-$ RII) \\
\hline Soluble cellular ligands & Anakinra (IL-1 receptor) \\
\hline Soluble receptor constructs & Ritanercept (IL-1 $\beta$ receptor) \\
\hline \multirow[t]{4}{*}{ Cytokines } & Interferon- $\alpha$ \\
\hline & Interferon- $\beta$ \\
\hline & GM-CSF \\
\hline & Interleukin-2 \\
\hline \multicolumn{2}{|c|}{$\begin{array}{l}C D \text { cluster of differentiation, IL interleukin, LFA lymphocyte function-as- } \\
\text { sociated antigen, TNF tumor necrosis factor, EGFR endothelial growth } \\
\text { factor receptor, HER human epidermal growth factor, GM-CSF granulocyte- } \\
\text { macrophage colony-stimulating factor } \\
\text { aAdapted from http://biologics.clinimmsoc.org (WEBbook of Biologic Thera- } \\
\text { pies) and Scherer et al. [1] with permission }\end{array}$} \\
\hline
\end{tabular}

Fusion proteins include soluble cytokine receptors, soluble cellular ligands, and soluble receptor constructs, and immunoglobulin fragments. Recombinant cytokines, including interferon- $\alpha$, interferon- $\beta$, granulocyte-macrophage colony-stimulating factor (GM-CSF), and interleukin (IL)-2, may also be effective treatments for various conditions.

Biologics that neutralize tumor necrosis factor $\alpha$ (TNF- $\alpha$ ), interferons, and ILs, or receptor blockers targeting receptors such as epidermal growth factor receptor (EGFR), eukaryotic ribosome biogenesis protein (Erb) 1, Erb2, and human clusters of differentiation (CD) 125 are currently available [3-5].

\section{International nomenclature of biotechnological substances}

Systems of nomenclature most commonly used are the World Health Organization's International Nonproprietary Names (INN) and the United States' Adopted Names (USAN) for biologicals [6, 7]. The syllables used in naming have various meanings.

The first one to two syllables have no specific meaning.

The second or third syllable defines the target or indication of the drugs. As used herein, -li/-lim designates the immune system, -tu/-ti designates tumors, -ki designates cytokines, -vi designates viruses, and -ci designates the cardiovascular system. Thus, oma- 
Table 2 Internationally accepted nomenclature of biotechnological substances $^{a}$

\begin{tabular}{|c|c|c|c|}
\hline Syllable & Explanation & Syllable & Explanation \\
\hline First & There is no specific meaning & - & - \\
\hline \multirow[t]{6}{*}{ Second or third } & \multirow[t]{6}{*}{ Target of the biological agent } & $-c i$ & Cardiovascular system \\
\hline & & $-k i$ & Cytokine, interleukin \\
\hline & & -li/-lim & Immune system \\
\hline & & $-t u /-t i$ & Tumor \\
\hline & & $-v i$ & Viral \\
\hline & & $-b a$ & Bacterial \\
\hline \multirow[t]{4}{*}{ Third or fourth } & \multirow[t]{4}{*}{ Source of the biological agent } & $-m o /-m u$ & Murine, mouse ( $0 \%$ human) \\
\hline & & $-x i$ & Chimeric (75\% human) \\
\hline & & $-z u$ & Humanized (>90\% human) \\
\hline & & $-u$ & (Fully) human ( $100 \%$ human) \\
\hline \multirow[t]{3}{*}{ Last } & \multirow[t]{3}{*}{ Mechanism of action } & $-m a b$ & Monoclonal antibody \\
\hline & & -cept & Soluble receptor \\
\hline & & $-i n i b$ & Receptor blocker \\
\hline
\end{tabular}

$l i$-zumab targets the immune system, ce-tu-ximab is an approved antitumor drug, pali- $v i$-zumab is used to prevent viral infections, ab-ci-ximab has a cardiovascular indication, and secu-kin-umab acts on IL-17a.

The third or fourth syllable names the source of the BS. Murine biologicals take -mo/-mu. They are produced from $100 \%$ murine genes and are the most potentially allergenic biologics (e.g., muro-mo-nab, blinatu-mo-mab). Chimeric antibodies (-xi) are only murine in their variable region, consisting of approximately $30 \%$ mouse protein (e.g., infli- $x i$-mab, cetu- $x i$ mab). Humanized antibodies' (-zu) variable regions are mostly human, consisting of mouse protein only in their complementarity-determining regions (CDR). These antibodies (e.g., omali- $z u$-mab, trastu- $z u$-mab) contain approximately 5\% non-human protein. Human biologicals $(-\mathrm{u})$ contain $100 \%$ human protein sequences (e.g., golim- $u$-mab, dupil- $u$-mab) and are the least allergenic. Human homologies are $0 \%, 75 \%$,
$>90 \%$, and $100 \%$, respectively [1]. The risk of allergic reactions decreases proportionally with the increase in human homology [8]. Many BSs have been abandoned due to the fact that they caused intolerable immunological/allergic reactions or lacked efficacy [9].

The last syllable defines the mechanism of action. MAbs are designated -mab, receptor-derived biologics are designated -cept, and receptor blockers are designated -inib (omalizu- $m a b$, etaner-cept, and imat-inib) (see Table 2).

\section{Classification of allergic reactions to biotechnological substances}

As clinical use and approved indications for BSs increase, reports of BS-associated adverse events increase in proportion. Five types of adverse side effects (alpha, beta, gamma, delta, and epsilon) were described by W.J. Pichler in 2006 (Table 3; [10]). The

Table 3 Classification of adverse drug reactions to biotechnological substances ${ }^{a}$

\begin{tabular}{|c|c|c|c|c|c|}
\hline Features & Type alpha $(\alpha)$ & Type beta ( $\beta)$ & Type gamma $(\gamma)$ & Type delta $(\delta)$ & Type epsilon $(\varepsilon)$ \\
\hline Nomenclature & $\begin{array}{l}\text { Cytokine release syn- } \\
\text { drome }\end{array}$ & Hypersensitivity & $\begin{array}{l}\text { Immune or cytokine imbal- } \\
\text { ance syndromes }\end{array}$ & Cross-reactivity & $\begin{array}{l}\text { Non-immunological } \\
\text { side effects }\end{array}$ \\
\hline Effect & $\begin{array}{l}\text { Pharmacological-toxic } \\
\text { reaction }\end{array}$ & $\begin{array}{l}\text { Immune-mediated } \\
\text { reactions }\end{array}$ & Immune deviation & $\begin{array}{l}\text { Appear after some time } \\
\text { of treatment (up to sev- } \\
\text { eral years) }\end{array}$ & $\begin{array}{l}\text { Unexpected physio- } \\
\text { logical effects and } \\
\text { functions of BS }\end{array}$ \\
\hline Dose & Dose-dependent & Dose-independent & - & - & - \\
\hline Mechanism & $\begin{array}{l}\text { Direct effect by cytokine } \\
\text { release }\end{array}$ & $\begin{array}{l}\text { Induction of antibod- } \\
\text { ies; T-cell involvement }\end{array}$ & $\begin{array}{l}\text { Immunosuppression or } \\
\text { autoimmunity }\end{array}$ & $\begin{array}{l}\text { Reactions with struc- } \\
\text { turally similar protein or } \\
\text { antigen }\end{array}$ & - \\
\hline Example & Infusion reactions & $\begin{array}{l}\text { Aspirin-induced } \\
\text { asthma, maculopapu- } \\
\text { lar exanthema, hyper- } \\
\text { sensitivity reactions } \\
\text { and anaphylaxis }\end{array}$ & $\begin{array}{l}\text { De novo induction of a SLE, } \\
\text { TBC under TNF- } \alpha \text {-blocking } \\
\text { therapy }\end{array}$ & $\begin{array}{l}\text { Acneiform eruptions ob- } \\
\text { served during anti-EGFR } \\
\text { treatment }\end{array}$ & $\begin{array}{l}\text { Role of TNF- } \alpha \\
\text { in heart failure, } \\
\text { neuropsychiatric } \\
\text { side effects and } \\
\text { retinopathies ob- } \\
\text { served during IFN- } \alpha \\
\text { treatments }\end{array}$ \\
\hline
\end{tabular}


Fig. 1 Classification of adverse drug reactions to biotechnological substances. (Modified from Scherer et al. [1] and Pichler [10] with permission)
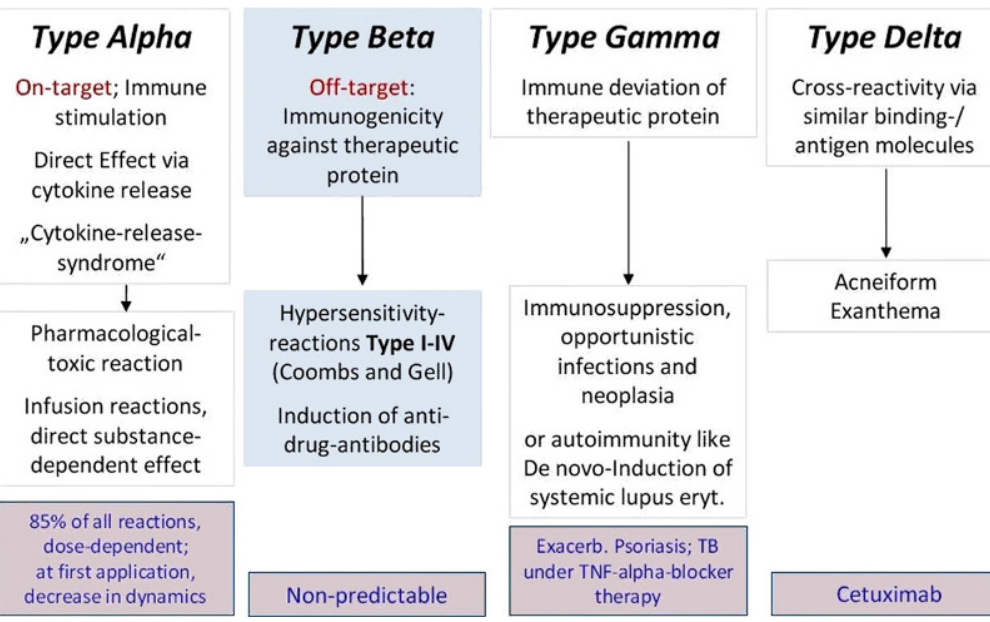

\section{Type Epsilon}

Non-immunological $\mathrm{AE}$; other effects of, for example, cytokines classification scheme of W.J. Pichler [10] has been accepted internationally and provides a useful framework for a better understanding of ADRs induced by BSs. This approach has helped define pathogenic mechanisms and manage/minimize broadband side effects (Fig. 1; [1, 10]). It has been stated that classifying and learning these HSRs is important for managing acute conditions [11].

Type-alpha ( $\alpha$ ) ADRs are also referred to as cytokine release syndrome and cytokine storm. These ADRs occur in response to high systemic concentrations of circulating cytokines or to sudden high rates of cytokine release into the circulation during treatment $[10,12]$. Cytokine release syndrome (CRS) can produce gastrointestinal symptoms (nausea, vomiting, diarrhoea), headache, myalgia, pulmonary edema, encephalopathy, aseptic meningitis, fever, arthralgia, and systemic capillary leak syndrome [12]. CRS can result in acute respiratory distress syndrome, cardiovascular shock, and multi-organ failure owing to systemic inflammatory responses [12-14]. These side effects usually occur during infusion at first administration and are dose-dependent [10].

Type- $\alpha$ reactions are divided into five levels by severity (referenced in [15]):

- Grade I: Mild reaction, no need to discontinue treatment, no additional intervention required

- Grade II: Intervention or termination of treatment required, responds quickly to pharmacological intervention

- Grade III: Long-term reaction, slow response to pharmacological intervention and/or treatment interruption; recurrence of symptoms; hospitalization

- Grade IV: Life-threatening reaction, requires vasopressor drug support and mechanical ventilation

- Class V: Death

Acute and delayed infusion reactions

Most BSs are administered intravenously, and thus may induce IRs. These reactions may be IgE- or non-
IgE mediated $[10,14,15]$. There is no consistent terminology in the literature that distinguishes acute IR from type- $\alpha$ or type- $\beta$ HSR [15]. Acute IRs typically appear during the first $15 \mathrm{~min}$ of the infusion, or as delayed IRs between $1 \mathrm{~h}$ to 14 days after the infusion (referenced in [14]). However, acute IRs occur in $3-5 \%$ of treatments with chimeric BSs within $1 \mathrm{~h}$ after the first infusion, and clinical manifestations can vary widely, ranging from mild to life-threatening [10-15]. Delayed IRs are usually accompanied by symptoms such as muscle and joint pain, pruritus, facial edema, fever, dysphagia, skin rash, and exanthema [10, 14].

Type-beta $(\beta)$ is an immediate (IgE-mediated) or delayed (IgG- and T-cell-mediated)-type HSR [10, 11]. Immediate (acute) reactions occur within 20-30 min after injection, and are most common in response to intravenous infusion. These reactions can disappear when the treatment is discontinued or the infusion rate is reduced. Consequently, tolerance can be induced. Delayed-type reactions may occur from $6 \mathrm{~h}$ after the start of treatment. They are usually mediated via T-cells or immunoglobulins and are drug dose-independent [10]. Examples include maculopapular exanthema and hypersensitivity reactions. The occurrence of these reactions depends on the immunogenicity of the BS. Risk is reduced in proportion to the BS's degree of humanization [8, 10]. Murine and chimeric antibodies are the most immunogenic due to the high percentage of foreign protein they contain. Humanized and (fully) human antibodies can still elicit systemic immune responses, but the risk is reduced considerably when compared to chimeric ones. They can also cause other ADRs by different mechanisms. Various other factors, such as the addition of adjuvants, route of administration (intravenous or subcutaneous), treatment protocol (intermittent or continuous), and simultaneous use of immunosuppressive drugs, also influence the risk of HSR. Organic compounds with adjuvant activity in the vehicle are believed to contribute to immunogenicity in cases of pure red cell aplasia associated 
Table 4 Pathomechanisms of hypersensitivity reactions ${ }^{a}$

\begin{tabular}{|c|c|c|c|c|c|c|c|}
\hline & \multicolumn{3}{|c|}{ Antibody-mediated hypersensitization } & \multicolumn{4}{|c|}{ Cell-mediated hypersensitization (Delayed) } \\
\hline & Type I & Type II (a and b) & Type III & Type IVa & Type IVb & Type IVc & Type IVd \\
\hline Mediator & $\lg \mathrm{E} ;$ non-lgE & IgG or IgM, complement & $\begin{array}{l}\text { lgG/lgM; com- } \\
\text { plement }\end{array}$ & T-helper 1 & T-helper 2 & $\begin{array}{l}\text { T-cells } \\
\left(\mathrm{CD}^{+}\right)\end{array}$ & T-cells \\
\hline Mechanism & $\begin{array}{l}\text { Mast cell activa- } \\
\text { tion }\end{array}$ & $\begin{array}{l}\text { Antibody- and/or com- } \\
\text { plement-mediated; } \\
\text { cytotoxic }\end{array}$ & $\begin{array}{l}\text { Immune com- } \\
\text { plexes }\end{array}$ & $\begin{array}{l}\text { Macrophage } \\
\text { activation }\end{array}$ & $\begin{array}{l}\text { Eosinophil } \\
\text { activation }\end{array}$ & $\begin{array}{l}\text { Cytotoxic } \\
\text { reactions }\end{array}$ & $\begin{array}{l}\text { Neutrophilic } \\
\text { inflammation }\end{array}$ \\
\hline \multirow[t]{6}{*}{$\begin{array}{l}\text { Clinical } \\
\text { presentation }\end{array}$} & Allergic rhinitis & $\begin{array}{l}\text { Autoimmune haemolytic } \\
\text { anemia }\end{array}$ & $\begin{array}{l}\text { Immune com- } \\
\text { plex vasculitis }\end{array}$ & $\begin{array}{l}\text { Contact dermati- } \\
\text { tis }\end{array}$ & $\begin{array}{l}\text { Chronic } \\
\text { asthma }\end{array}$ & $\begin{array}{l}\text { Contact } \\
\text { dermatitis }\end{array}$ & AGEP \\
\hline & Anaphylaxis & $\begin{array}{l}\text { Antibody-mediated } \\
\text { glomerulonephritis }\end{array}$ & $\begin{array}{l}\text { Serum sick- } \\
\text { ness-like } \\
\text { reaction }\end{array}$ & \multirow[t]{5}{*}{ Type I Diabetes } & \multirow[t]{5}{*}{$\begin{array}{l}\text { Chronic } \\
\text { allergic rhinitis }\end{array}$} & SJS & Behcet disease \\
\hline & Angioedema & $\begin{array}{l}\text { Chronic urticaria (idio- } \\
\text { pathic) }\end{array}$ & Arthus reaction & & & \multirow[t]{4}{*}{ TEN } & \multirow[t]{4}{*}{ Pustular psoriasis } \\
\hline & Asthma & Drug-induced cytopenia & Arthritis & & & & \\
\hline & \multirow[t]{2}{*}{ Urticaria } & Graves Disease & Nephritis & & & & \\
\hline & & Penicillin allergy & SLE & & & & \\
\hline
\end{tabular}

with erythropoietin injections [16]. In addition, it is a well-known fact that combining infliximab therapy with methotrexate reduces sensitivity, immunogenicity, and the formation of anti-infliximab antibodies $[17,18]$.

Delayed or non-IgE-mediated reactions can cause local reactions at injection sites, or generalized urticaria and anaphylaxis. These types of allergic reactions are often mild, but more severe reactions such as IgE-mediated anaphylaxis have been described [19]. Formation of (mostly neutralizing) antibodies against BSc occur in a wide variation of frequency, depending on the BS structure, serum-drug levels, concomitant teatment and patient-related factors [20]. TNF-alpha inhibitors also induce autoimmune phenomena including autoantibodies, lupus-like syndrome and direct antigen-mediated hypersensitivity vasculitis [21], the latter probably due to immune complexes.

- Hypersensitivity reactions (type- $\beta$ ) are graded according to severity as follows [15, 22]:

- Grade I: Transient flush, rash, drug-induced fever $<38^{\circ} \mathrm{C}$

- Grade II: Flush, rash, exanthema, urticaria, and dyspnea, drug-induced fever $\geq 38^{\circ} \mathrm{C}$

- Grade III: Symptomatic bronchospasm with or without urticaria, hypotension, and angioedema

- Grade IV: Anaphylaxis (is not consistently clarified in the literature, probably grade III/grade IV)

- Grade V: Death

Classical grading of hypersensitivity reactions by Gell and Coombs

The immune system responds in various ways to different factors. These factors include bacteria, viruses, fungi, and allergens. The primary goal of each response is to protect the host. Sometimes, the immune system produces an excessive response. This is called hypersensitivity. The classical Gell and Coombs classification system [23] divides HSRs into four subtypes according to factor, type of immunological response, as well as cell and tissue damage (Table 4; $[23,24]$ ):

- Type I, due to mast cell activation, immediate, IgEmediated

- Type II, associated with antibodies, cytotoxic, IgG-/IgM-mediated, complement

- Type III, mediated by immune complexes and IgG/IgM, complement

- Type IV, delayed-type hypersensitivity reactions, mediated by T-helper and T-cytotoxic cells

Penicillin can cause any of these HSR types, for example: type I, anaphylaxis, angioedema, and urticaria; type II, hemolytic anemia, cytopenia; type III, serum sickness-like reaction; and type IV, delayed type skin rash or contact dermatitis [24]. In clinical practice, the anaphylactic reaction to contrast agents used in radiology is a non-IgE-mediated HSR, a pseudoallergy, and can be prevented by pretreatment with corticosteroids and antihistamines, whereas IgE-mediated anaphylaxis cannot be prevented by pharmacological pre-treatment alone.

\section{Ring and Messmer's anaphylaxis grading system}

The term "anaphylaxis" refers to an acute reaction that affects specific organ systems or the entire organism. Anaphylactic reactions can affect skin and mucous membranes, the respiratory system, the gastrointestinal system, the cardiovascular, and the nervous system and can trigger specific symptoms. The term, "anaphylactic shock" was coined to describe a condition characterized by life-threatening symptoms including sudden respiratory distress, hypotension, as well as cardiac and circulatory failure within a few minutes of contact with the allergen. The grading sys- 
Table 5 Grading of anaphylaxis ${ }^{\mathrm{a}}$

\begin{tabular}{|c|c|c|c|c|}
\hline Systems & Grade I & Grade ॥ & Grade III & Grade IV \\
\hline $\begin{array}{l}\text { Skin and subjective } \\
\text { symptoms }\end{array}$ & $\begin{array}{l}\text { Pruritus, flush } \\
\text { urticaria, angioedema }\end{array}$ & $\begin{array}{l}\text { Pruritus, flush } \\
\text { urticaria, angioedema }\end{array}$ & $\begin{array}{l}\text { Pruritus, flush } \\
\text { urticaria, angioedema }\end{array}$ & $\begin{array}{l}\text { Pruritus, flush } \\
\text { urticaria, angioedema }\end{array}$ \\
\hline Abdominal & - & $\begin{array}{l}\text { Nausea, } \\
\text { abdominal cramps, vomiting }\end{array}$ & $\begin{array}{l}\text { Vomiting, } \\
\text { defecation }\end{array}$ & $\begin{array}{l}\text { Vomiting, } \\
\text { defecation }\end{array}$ \\
\hline Respiratory & - & $\begin{array}{l}\text { Rhinorrhea, } \\
\text { hoarseness, } \\
\text { dyspnea }\end{array}$ & $\begin{array}{l}\text { Laryngeal edema, } \\
\text { bronchospasm, } \\
\text { cyanosis }\end{array}$ & Respiratory arrest \\
\hline Cardiovascular & - & $\begin{array}{l}\text { Tachycardia }^{\mathrm{b}} \text {, } \\
{\text { blood pressure change }{ }^{\mathrm{c}}}^{\mathrm{c}} \\
\text { arrhythmia }\end{array}$ & Shock & Cardiac arrest \\
\hline
\end{tabular}

tem was suggested by Ring and Messmer in 1977 [25] and is still valid, based on the severity of the clinical manifestations and organ involvement (Table 5; [26]). Anaphylaxis is an example of type I hypersensitivity according to Gell and Coombs [23].

Type-gamma $(\gamma)$ responses are also called immune or cytokine imbalance syndromes [10]. These ADRs include immune system depression or autoimmunity caused by the immune system and cytokine imbalances. Skin-prick tests (SPT) and in vitro assays for anti-drug antibodies (ADA) are generally negative [10]; ADA might be detectable but are of no relevance for type-gamma reactions. BSs can cause immunodeficiencies that are beneficial in treating a condition, but will facilitate invasion by or activation of opportunistic pathogens that have remained under control such as tuberculosis, fungal infections, or herpes zoster. BSs can also result in imbalances in the immune system by mechanisms that are not fully understood. The use of BSs may trigger autoimmune diseases such as lupus-like syndrome, autoimmune thyroid disease, Guillain-Barre syndrome, vasculitis, psoriasis, idiopathic thrombocytopenic purpura, and systemic sclerosis [10]. One possible mechanism of action is the alteration of the T-helper 1 (Th1)/Th2 balance by alteration of central and peripheral tolerance mechanisms. Other possibilities include alteration of regulatory $\mathrm{T}$ cells and change in levels of certain cytokines such as transforming growth factor (TGF- $\beta$ ) and IL-10 [27].

Type-delta $(\delta)$ ADRs are also called cross-reactions. These side effects may be caused by antibodies produced in response to an antigen expressed on the targeted cells, which may cross-react with an antigen on normal host cells $[10,28]$. For example, some publications indicate that the EGFR is strongly expressed in various carcinomas and plays a role in tumor progression [29]. However, this receptor also plays an important role in epidermal homeostasis. Therapeutic antibodies against EGFR (e.g., cetuximab) are used to treat various tumors. Acneiform eruptions are quite common during these treatments, probably owing to the effects of anti-EGFR antibodies on the epidermal cells [28]. Some antibodies used as treatments may cause unexpected side effects by interacting with structurally similar proteins.

Type-epsilon ( $\varepsilon$ ) ADRs represent non-immunologic side effects. This newly defined type tries to explain BS-mediated impairment of other physiological functions in the body. The promotion of heart failure by anti-TNF- $\alpha$ agents, as well as the neuropsychiatric side effects and retinopathy caused by IFN- $\alpha$, may represent type $\varepsilon$ ADRs [30-32]. Such unexpected and interesting side effects of BSs offer researchers opportunities to detect new functions of established drugs.

\section{Diagnostic measures}

So far, no established and approved routine (allergy) diagnostic test exists for the diagnosis of the different immune reactions to BSs. Today, a variety of nonstandardized methods are used to support the clinical diagnosis (Fig. 2; [33]). These are SPT applied as prickto-prick tests and intradermal tests with the drug itself and its potentially allergenic ingredients. In vitro diagnostic tests are established in routine diagnostic laboratories for the detection of ADA, a test basically used for the detection of anti-drug-IgG antibodies that are associated with the loss of efficacy to a biological.

Some laboratories also provide tests for the detection of anti-drug IgE, which has not yet been routinely established. Serum tryptase concentration, which increases during anaphylactic reactions, is a very helpful parameter to support the clinical diagnosis of anaphylaxis to a BS in its acute state. It is, however, rarely used by the physicians in charge of the patients while the event occurs, and when the patients are subsequently referred to an allergy outpatient clinic for detailed exploration, serum tryptase is within its normal range again. The authors strongly recommend using this diagnostic tool regularly in cases of HSR. Basophil activation tests or lymphocyte stimulation tests have also been shown to add valuable informa- 


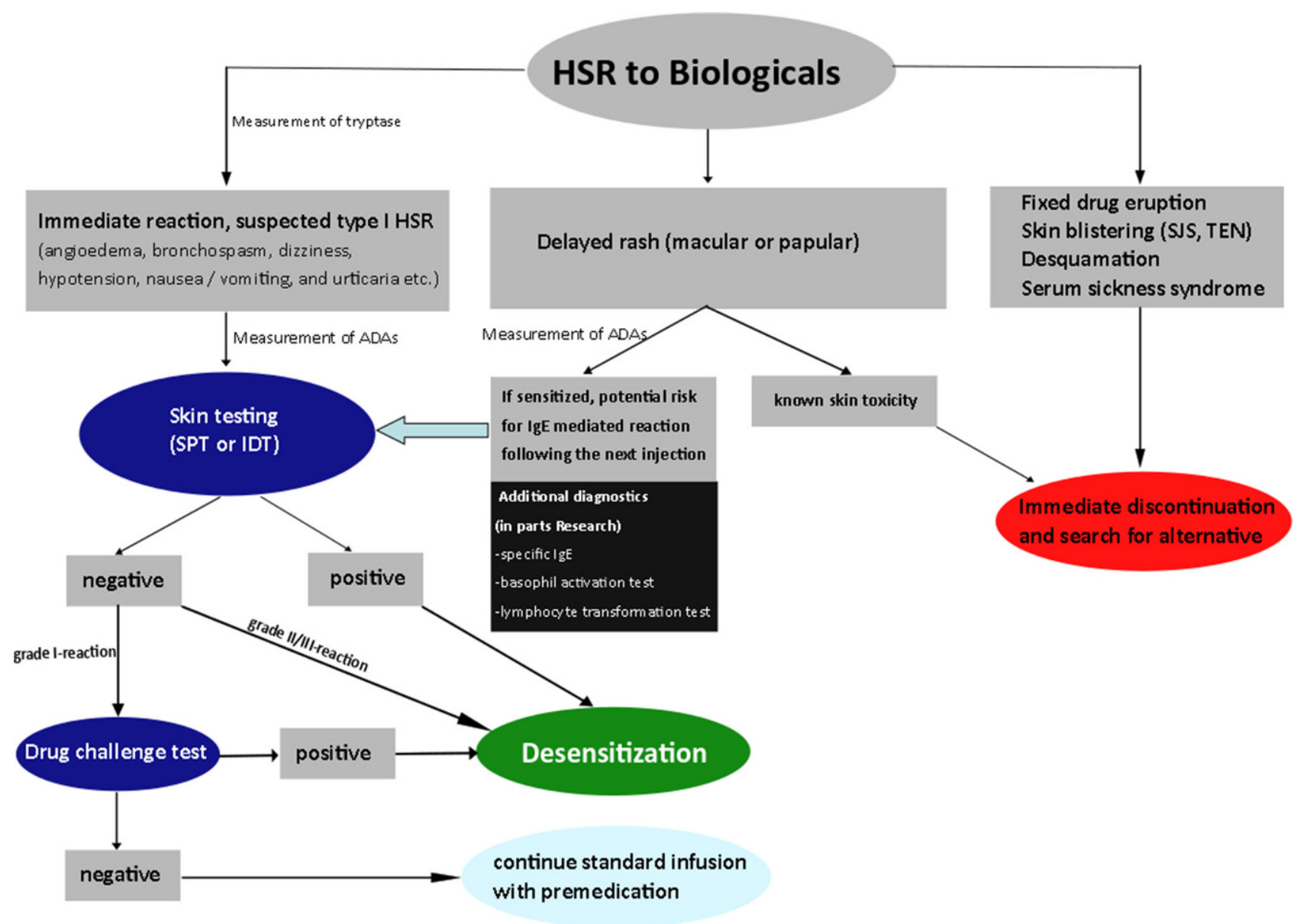

Fig. 2 Diagnostic algorithm after a hypersensitivity reaction ${ }^{\mathrm{a}}$. (HSR hypersensitivity reactions, SJS Stevens-Johnson syndrome, TEN toxic epidermal necrolysis, SPT skin prick test,

tion, but have not yet been studied on large patient groups.

\section{Skin prick test and intradermal test}

Skin tests are generally recommended to be performed 2-4 weeks after a suspected HSR has occurred. Specific IgE antibodies may be depleted in the first days/weeks after the reaction, and this may lead to a false negative result. Generally known non-irritant concentrations for SPT and intradermal testing are given in Table 6 [33-37]. Unfortunately, there is no specific test concentration, sensitivity, or specificity for all BSs. Whenever the drug itself is used for diagnostic purposes, it is considered "off-labeluse," to which the patients should declare their informed consent in writing. According to Cox et al. [38], no irritant reactions, adverse events, or IgG antibodies developed after SPT with omalizumab. An intradermal test with, for example, omalizumab at a concentration of 1:100,000 $(\sim 1.25 \mu \mathrm{g}$ of omalizumab per $\mathrm{ml}$ ) could be safely applied without inducing irritant reactions [39].
IDT intradermal test. aAdapted from Hsu Blatman et al. [33] with permission and modified)

\section{Serum tryptase level}

Tryptase is an enzyme produced from mast cells that reflects anaphylactic reactions and mast cell diseases. The most accurate time for serum sampling is 30-120 min after the start of the reaction (referenced in [40]). However, it should be kept in mind that normal tryptase levels can be observed, and basophil mediators may play a role in immediate type HSRs. Nonetheless, the authors strongly recommend using this diagnostic tool regularly in cases of HSR.

\section{Drug challenge test}

The drug challenge test can be performed if skin tests are negative, tryptase levels are within normal range, and clinical findings are not indicative for a true IgEmediated allergic reaction [33, 40]. This test is performed in cases of previous immediate reactions, administering between $1 / 10,000$ and $1 / 10$ of the total dose of the drug under medical supervision. If the patient tolerates the drug, the regular infusion is continued. In addition, it should be noted that the initial dose of the test should not exceed 1/100 of the therapeutic dose in patients that had previously developed non-immediate reactions during medical treat- 
Table 6 Non-irritant concentrations of biotechnological substances for skin prick test (SPT) and intradermal test (IDT) ${ }^{\mathrm{a}}$

\begin{tabular}{|c|c|c|c|}
\hline Drug & SPT & IDT & References \\
\hline Abciximab & $0.2-2.0 \mathrm{mg} / \mathrm{mL}$ & $0.2-2.0 \mathrm{mg} / \mathrm{mL}$ & Referenced in Corominas et al., 2014 [35] \\
\hline Abatacept & $25 \mathrm{mg} / \mathrm{mL}$ & $0.025-0.25-2.5 \mathrm{mg} / \mathrm{mL}$ & Referenced in Hsu Blatman et al., 2014 [33] \\
\hline Anakinra & As is & - & Referenced in Corominas et al., 2014 [35] \\
\hline \multirow[t]{2}{*}{ Adalimumab } & $40.0 \mathrm{mg} / \mathrm{mL}$ & $0.4 \mathrm{mg} / \mathrm{mL}$ & Referenced in Isabwe et al., 2017 [34], and in Picard et al., 2017 [36] \\
\hline & $50.0 \mathrm{mg} / \mathrm{mL}$ & $5-50.0 \mathrm{mg} / \mathrm{mL}$ & Referenced in Corominas et al., 2014 [35] \\
\hline Basiliximab & $4 \mathrm{mg} / \mathrm{mL}$ & $0.4-400 \mu \mathrm{g} / \mathrm{mL}$ & Referenced in Corominas et al., 2014 [35] \\
\hline Bevacizumab & $25 \mathrm{mg} / \mathrm{mL}$ & $0.25-2.5-25.0 \mathrm{mg} / \mathrm{mL}$ & Castels et al., 2017 [37] \\
\hline \multirow[t]{3}{*}{ Cetuximab } & $2 \mathrm{mg} / \mathrm{mL}$ & $0.2 \mathrm{mg} / \mathrm{mL}$ & Referenced in Isabwe et al., 2017 [34], and in Picard et al., 2017 [36] \\
\hline & $20 \mathrm{mg} / \mathrm{mL}$ & $0.2-2.0-20.0 \mathrm{mg} / \mathrm{mL}$ & Castels et al., 2017 [37] \\
\hline & $500 \mu \mathrm{g} / \mathrm{mL}$ & $5-50-500 \mu \mathrm{g} / \mathrm{mL}$ & Referenced in Corominas et al., 2014 [35] \\
\hline \multirow[t]{3}{*}{ Etanercept } & $25 \mathrm{mg} / \mathrm{mL}$ & $5 \mathrm{mg} / \mathrm{mL}$ & Referenced in Corominas et al., 2014 [35] \\
\hline & $50 \mathrm{mg} / \mathrm{mL}$ & $0.5 \mathrm{mg} / \mathrm{mL}$ & Referenced in Isabwe et al., 2017 [34], and in Picard et al., 2017 [36] \\
\hline & $50 \mathrm{mg} / \mathrm{mL}$ & $0.05-0.5-5.0 \mathrm{mg} / \mathrm{mL}$ & Referenced in Hsu Blatman et al., 2014 [33] \\
\hline \multirow[t]{2}{*}{ Infliximab } & $10 \mathrm{mg} / \mathrm{mL}$ & $0.1-1.0 \mathrm{mg} / \mathrm{mL}$ & Referenced in Corominas et al., 2014 [35] \\
\hline & $10 \mathrm{mg} / \mathrm{mL}$ & $0.1-1.0-10.0 \mathrm{mg} / \mathrm{mL}$ & Castels et al., 2017 [37] \\
\hline Natalizumab & $20 \mathrm{mg} / \mathrm{mL}$ & $2 \mathrm{mg} / \mathrm{mL}$ & Referenced in Corominas et al., 2014 [35] \\
\hline Omalizumab & $12.5-125 \mathrm{mg} / \mathrm{mL}$ & $1.25 \mu \mathrm{g} / \mathrm{mL}$ & Referenced in Corominas et al., 2014 [35] \\
\hline Pertuzumab & $1.6 \mathrm{mg} / \mathrm{mL}(1 / 20)$ & $0.16 \mathrm{mg} / \mathrm{mL}$ & Referenced in Picard et al., 2017 [36] \\
\hline \multirow[t]{3}{*}{ Rituximab } & $10 \mathrm{mg} / \mathrm{mL}$ & $0.01-0.1-1.0 \mathrm{mg} / \mathrm{mL}$ & Referenced in Hsu Blatman et al., 2014 [33] \\
\hline & $10 \mathrm{mg} / \mathrm{mL}$ & $0.10-1.0 \mathrm{mg} / \mathrm{mL}$ & Referenced in Corominas et al., 2014 [35] \\
\hline & $10 \mathrm{mg} / \mathrm{mL}$ & $0.10-1.0-10.0 \mathrm{mg} / \mathrm{mL}$ & Castels et al., 2017 [37] \\
\hline Tocilizumab & $20 \mathrm{mg} / \mathrm{mL}$ & $0.2-2.0-20.0 \mathrm{mg} / \mathrm{mL}$ & Castels et al., 2017 [37] \\
\hline \multirow[t]{2}{*}{ Trastuzumab } & $21 \mathrm{mg} / \mathrm{mL}$ & $0.21-2.1 \mathrm{mg} / \mathrm{mL}$ & Referenced in Corominas et al., 2014 [35] \\
\hline & $21 \mathrm{mg} / \mathrm{mL}$ & $0.21-2.1-21.0 \mathrm{mg} / \mathrm{mL}$ & Castels et al., 2017 [37] \\
\hline
\end{tabular}

ment [41]. A positive test result indicates that the patient may profit from desensitization to the drug. Drug challenge should also not be performed in severe forms of delayed-type hypersensitivity.

\section{Anti-drug antibodies}

BSs are potentially immunogenic drugs that technically affect and alter the immune system. As a result, ADAs are produced and may cause various HSRs and side effects. The majority of ADAs comprise the IgG class, as well as IgG subclasses (IgG 1-4), which are mainly investigated in cases of reduced efficacy (neutralizing effect) [20]. However, multiple isotypes (IgE, IgM, and IgG) can be detected during HSR [14, 42, 43] and are involved in severe HSR to certain BSs, such as infliximab, where they can be effective in predicting the reaction $[42,43]$.

Two types of HSR related to antibodies have been identified: acute and delayed, but many do not appear to be IgE-mediated/anaphylactic [44]. However, nonIgE ADAs represented by IgG can lead to acute infusion reaction via complement activation, and - shown in animal models - involving Fc gamma RIII, neutrophils, macrophages, and basophils [45]. It has been reported that the antibody concentrations decrease with the concomitant use of immunosuppressants together with BSs [1]. Some ADA testing for various BSs (abatacept, adalimumab, certolizumab, etanercept, golimumab, infliximab, natalizumab, nivolumab, omalizumab, rituximab, tocilizumab, trastuzumab, ustekinumab, and vedolizumab) is commercially available in the European Union through a Dutch company (www.sanquin.org).

An enzyme-linked immunosorbent assay (ELISA; ImmunoCAP, Thermofisher Scientific), which can detect anti-cetuximab IgE, has been developed to identify treatment-associated IgE-mediated cases of HSR, and possibly identifies patients with increased risk of allergic side effects. Own investigations on potential allergenic peptide epitopes on infliximab and adalimumab, both TNF- $\alpha$-inhibitors, revealed some allergenic epitopes that are recognized by patients' Ig antibodies (IgG and IgE). In a proof of principle study, we could show that neutralizing ADAs bind to epitopes in the pharmacologically relevant TNF- $\alpha$ binding site [46], providing the elucidation of the mechanism for the loss of efficacy of the drug in patients with ADA. In subsequent investigations, we could show that these epitopes were not cross-reactive between both biologicals [47]. These results confirmed a clinical observation by Steenholdt and co-authors, who described a patient with Crohn's disease and acute non-IgE-mediated but ADA-positive anaphylactoid reaction to infliximab [48]. The patient was subsequently treated with adalimumab and developed a delayed reaction based on rapidly 
Table 7 Additional mostly inactive ingredients of biotechnological substances ${ }^{\mathrm{a}}$

\begin{tabular}{|c|c|}
\hline Drugs & Components \\
\hline Abciximab & Polysorbate 80 , sodium chloride, sodium phosphate \\
\hline Adalimumab & $\begin{array}{l}\text { Polysorbate } 80 \text {, mannitol, sodium chloride, monobasic sodium phosphate dihydrate, dibasic sodium, phosphate dihydrate, sodium } \\
\text { citrate, citric acid monohydrate }\end{array}$ \\
\hline Aflibercept & $\begin{array}{l}\text { Polysorbate 20, sucrose, sodium chloride, sodium citrate dihydrate, citric acid monohydrate, sodium phosphate dibasic heptahy- } \\
\text { drate, sodium phosphate monobasic monohydrate, sodium hydroxide and/or hydrochloric acid }\end{array}$ \\
\hline Alefacept & Citric acid monohydrate, glycine, sodium citrate, sucrose \\
\hline Alemtuzumab & $\begin{array}{l}\text { Polysorbate } 80 \text {, dibasic sodium phosphate, disodium edetate dihydrate, potassium chloride, potassium dihydrogen phosphate, } \\
\text { sodium chloride }\end{array}$ \\
\hline Anakinra & Polysorbate 80 , sodium hydroxide, anhydrous citric acid, sodium chloride, disodium edetate \\
\hline Atezolizumab & Polysorbate 20 , sucrose, L-histidine, glacial acetic acid \\
\hline Basiliximab & Potassium phosphate monobasic, sodium phosphate dibasic anhydrous, sodium chloride, sucrose, mannitol, glycine \\
\hline Belatacept & Monobasic sodium phosphate, sodium chloride, and sucrose \\
\hline Belimumab & $\begin{array}{l}\text { Polysorbate } 80 \text {, citric acid, sodium citrate, sucrose for IV infusion. Polysorbate } 80 \text {, L-arginine hydrochloride, L-histidine, L-histidine } \\
\text { monohydrochloride, and sodium chloride for SC injection }\end{array}$ \\
\hline Benralizumab & Polysorbate 20, L-histidine, L-histidine hydrochloride monohydrate, $\alpha$-trehalose dihydrate \\
\hline Bevacizumab & Polysorbate 20 ,trehalose dihydrate, monobasic monohydrate sodium phosphate, dibasic sodium phosphate \\
\hline Blinatumomab & Polysorbate 80 , citric acid monohydrate, lysine hydrochloride, trehalose dihydrate, sodium hydroxide \\
\hline Canakinumab & Polysorbate 80 , histidine, histidine hydrochloride monohydrate, sucrose and mannitol \\
\hline Certolizumab & Polysorbate 20 , lactic acid, sucrose for injection. The prefilled syringe contains sodium acetate and sodium chloride \\
\hline Cetuximab & Sodium chloride, sodium phosphate, sodium hydroxide, hydrochloric acid or citric acid \\
\hline Daclizumab & Polysorbate 80 , sodium succinate, succinic acid, sodium chloride \\
\hline Dupilumab & Polysorbate 80 , L-arginine hydrochloride, L-histidine, sodium acetate, sucrose \\
\hline Durvalumab & Polysorbate 80, L-histidine, L-histidine hydrochloride monohydrate, $\alpha$-trehalose dihydrate \\
\hline Eculizumab & Polysorbate 80 , sodium chloride, sodium phosphate monobasic and dibasic \\
\hline Efalizumab & Polysorbate 20, L-histidine hydrochloride, L-histidine, sucrose \\
\hline Etanercept & Sodium chloride, L-arginine hydrochloride, sodium phosphate, and sucrose \\
\hline $\begin{array}{l}\text { Gemtuzumab ozogam- } \\
\text { icin }\end{array}$ & Dextran 40, sodium chloride, sodium phosphate dibasic anhydrous, sodium phosphate monobasic, sucrose \\
\hline Golimumab & Polysorbate 80, L-histidine, L-histidine monohydrochloride monohydrate, and sorbitol \\
\hline Ibritumomab tiuxetan & Sodium chloride \\
\hline Imatinib & $\begin{array}{l}\text { Colloidal silicon dioxide, crospovidone, hypromellose, magnesium stearate, microcrystalline cellulose, polyethylene glycol, polyvinyl } \\
\text { alcohol, red iron oxide (E172), talc, titanium dioxide (E171) and yellow iron oxide (E172) for tablets. Crospovidone, sodium stearyl } \\
\text { fumarate, gelatin, water, sodium lauryl sulfate, titanium dioxide, iron oxide yellow for capsules }\end{array}$ \\
\hline Infliximab & Polysorbate 80 , dibasic sodium phosphate dihydrate, monobasic sodium phosphate monohydrate, and sucrose \\
\hline Ipilimumab & Polysorbate 80 (vegetable origin), diethylene triamine pentaacetic acid, mannitol, sodium chloride, tris hydrochloride \\
\hline Ixekizumab & Polysorbate 80 , citric acid anhydrous, sodium chloride, sodium citrate dihydrate \\
\hline Lanadelumab & Polysorbate 80 , citric acid monohydrate, disodium phosphate dehydrate, L-histidine, sodium chloride \\
\hline Lebrikizumab & No information \\
\hline Ligelizumab & No information \\
\hline Mepolizumab & $\begin{array}{l}\text { Polysorbate } 80 \text {, sodium phosphate dibasic heptahydrate, and sucrose. In addition, citric acid monohydrate, EDTA disodium dihydrate } \\
\text { for prefilled syringe }\end{array}$ \\
\hline Muromonab & Polysorbate 80 , monobasic sodium phosphate, dibasic sodium phosphate, sodium chloride \\
\hline Natalizumab & Polysorbate 80 , sodium chloride, sodium phosphate, monobasic, monohydrate; sodium phosphate, dibasic \\
\hline Necitumumab & $\begin{array}{l}\text { Polysorbate } 80 \text { (E433), sodium citrate dihydrate (E331), citric acid anhydrous (E330), sodium chloride, glycine (E640), mannitol } \\
\text { (E421) }\end{array}$ \\
\hline Nivolumab & Polysorbate 80 , sodium citrate dihydrate, sodium chloride, mannitol (E421), pentetic acid, sodium hydroxide, hydrochloric acid \\
\hline Omalizumab & Polysorbate 20, L-arginine hydrochloride, L-histidine hydrochloride, L-histidine \\
\hline Panitumumab & Sodium chloride, sodium acetate \\
\hline Palivizumab & Chloride, glycine, and histidine \\
\hline Pembrolizumab & Polysorbate 80, L-histidine, L-histidine hydrochloride monohydrate, sucrose \\
\hline Pertuzumab & Polysorbate 20, L-histidine, sucrose \\
\hline Ramucirumab & Polysorbate 80 , histidine, histidine monohydrochloride, sodium chloride, glycine \\
\hline Reslizumab & Sodium acetate, sucrose, glacial acetic acid \\
\hline Rituximab & Polysorbate 80 , sodium chloride, sodium citrate dihydrate \\
\hline
\end{tabular}


Table 7 (Continued)

\begin{tabular}{|c|c|}
\hline Drugs & Components \\
\hline Secukinumab & Polysorbate $80, \alpha$-trehalose dihydrate, L-histidine hydrochloride-monohydrate, L-histidine, L-methionine \\
\hline Tocilizumab & $\begin{array}{l}\text { Polysorbate } 80 \text { and sucrose for IV infusion. In addition; L-arginine hydrochloride, L-histidine, L-histidine hydrochloride monohydrate, } \\
\text { and L-methionine for SC injection }\end{array}$ \\
\hline Trastuzumab & Polysorbate $20, \alpha$-trehalose dihydrate, L-histidine $\mathrm{HCl}$ monohydrate, L-histidine \\
\hline Ustekinumab & $\begin{array}{l}\text { Polysorbate } 80 \text {, L-histidine and L-histidine monohydrochloride monohydrate, and sucrose for SC injection. In addition; EDTA dis- } \\
\text { odium salt dihydrate, and L-methionine for IV infusion }\end{array}$ \\
\hline
\end{tabular}

developing ADA to adalimumab; however, no crossreactivity could be proven in vitro.

It is still too early to postulate that no cross-reactions may occur, and further epitopes will need to be identified and be made available for diagnostic tests. Some investigations have been performed on the subject of ADA to omalizumab in different formulations (lyophilized and in pre-filled syringes). No ADA were detectable [49]. No correlation between anaphylaxis and ADA (IgE, IgG) was demonstrated [50].

\section{Alpha-gal-specific IgE test}

Allergen-specific IgE assays may be useful to confirm allergic reactions to certain chimeric BSs containing the galactose- $\alpha$-1,3-galactose ( $\alpha$-gal) component, such as cetuximab, infliximab, and reslizumab. Although its clinical relevance is not fully understood due to the fact that it is different for $\alpha$-gal-containing biologicals, it may be useful in predicting allergic reactions and, subsequently, monitoring the potential development of IgE-mediated reactions. In the case of cetuximab, pre-existing IgE to $\alpha$-gal, e.g., due to sensitization via tick bites, were detected [51]. In order to perform useful treatment monitoring, the

Table 8 Potentially allergenic excipients in biotechnological substances ${ }^{a}$

\begin{tabular}{|c|c|c|c|c|c|}
\hline Polysorbate 80 & Polysorbate 20 & Sucrose & Mannitol & Trehalose & Glycine \\
\hline Abciximab & Aflibercept & Aflibercept & Adalimumab & Benralizumab & Alefacept \\
\hline Adalimumab & Atezolizumab & Alefacept & Basiliximab & Bevacizumab & Basiliximab \\
\hline Alemtuzumab & Benralizumab & Atezolizumab & Canakinumab & Blinatumomab & Necitumumab \\
\hline Anakinra & Bevacizumab & Basiliximab & Etanercept & Durvalumab & Palivizumab \\
\hline Belimumab & Certolizumab & Belatacept & Ipilimumab & Secukinumab & Ramucirumab \\
\hline Blinatumomab & Efalizumab & Belimumab & Interferon $\beta$-1a & \multirow[t]{14}{*}{ Trastuzumab } & \\
\hline Canakinumab & Omalizumab & Canakinumab & Interferon $\beta-1 b$ & & \\
\hline Daclizumab & Pertuzumab & Certolizumab & Interferon $\gamma-1 b$ & & \\
\hline Dupilumab & \multirow[t]{11}{*}{ Trastuzumab } & Dupilumab & Lenograstim & & \\
\hline Durvalumab & & Efalizumab & Necitumumab & & \\
\hline Eculizumab & & Etanercept & Nivolumab & & \\
\hline Golimumab & & Gemtuzumab & \multirow[t]{8}{*}{ Palivizumab } & & \\
\hline Infliximab & & Infliximab & & & \\
\hline Ipilimumab & & Mepolizumab & & & \\
\hline Ixekizumab & & Pembrolizumab & & & \\
\hline Lanadelumab & & Pertuzumab & & & \\
\hline Mepolizumab & & Reslizumab & & & \\
\hline Muromonab & & Ustekinumab & & & \\
\hline Natalizumab & & & & & \\
\hline Necitumumab & Latex & Albumin & Sodium acetate & Dextran 40 & Trometamol \\
\hline Nivolumab & Adalimumab & Interferon $\beta$-1a & Panitumumab & \multirow[t]{7}{*}{ Gemtuzumab } & Etanercept \\
\hline Pembrolizumab & Anakinra & Interferon $\beta-1 b$ & Certolizumab & & \\
\hline Ramucirumab & \multirow[t]{5}{*}{ Etanercept } & \multirow[t]{5}{*}{ Interferon $\alpha-2 b$} & Dupilumab & & Sorbitol \\
\hline Rituximab & & & \multirow[t]{4}{*}{ Reslizumab } & & Golimumab \\
\hline Secukinumab & & & & & \\
\hline Tocilizumab & & & & & Papain \\
\hline Ustekinumab & & & & & Abciximab \\
\hline
\end{tabular}


Table 9 Classification of the severity of infusion reactions and infusion center protocols ${ }^{\mathrm{a}}$

\begin{tabular}{|c|c|c|}
\hline Grade & Description & Therapy protocol \\
\hline I-Mild & $\begin{array}{l}\text { Mild and transient response, no indication for interruption of the infusion, } \\
\text { no indication for intervention }\end{array}$ & No indication for intervention \\
\hline $\begin{array}{l}\|- \text { Mild to moder- } \\
\text { ate }\end{array}$ & $\begin{array}{l}\text { Indication for therapy or discontinuation of the infusion, but with no imme- } \\
\text { diate response to symptomatic treatment (e.g., antihistamines, NSAIDs, } \\
\text { narcotics, i.v. fluids), prophylactic medications indicated for } \leq 24 \mathrm{~h}\end{array}$ & $\begin{array}{l}\text { Temporary interruption of the infusion, use of rescue } \\
\text { medication, if necessary; infusion resumed after complete } \\
\text { resolution of symptoms }\end{array}$ \\
\hline III-Moderate & $\begin{array}{l}\text { Brief or prolonged interruption of the infusion (e.g., no rapid response to } \\
\text { symptomatic medications); recurrence of symptoms after initial improve- } \\
\text { ment: hospitalization indicated for other clinical sequelae }\end{array}$ & $\begin{array}{l}\text { Temporary interruption of the infusion and use of rescue } \\
\text { medication; infusion resumed after complete resolution of } \\
\text { symptoms. Discontinuation of the procedure considered }\end{array}$ \\
\hline IV-Severe & Life-threatening consequences; urgent intervention indicated & $\begin{array}{l}\text { Interruption of the infusion and use of rescue medication } \\
\text { and hemodynamic support. } \\
\text { Discontinuation of the procedure }\end{array}$ \\
\hline V-Severe & Death & Death \\
\hline
\end{tabular}

serum of patients treated with biologicals should be investigated before, under, and after treatment (monitoring for Ig development). With regard to $\alpha$-gal, an IgE detection assay, the ImmunoCAP (Thermo Fisher Scientific) is available for routine allergy diagnostics. However, it may not always be sensitive enough [52].

\section{Inactive substances and potentially allergenic} ingredients in biotechnological substances

BSs contain additional inactive components or substances such as albumin, arginine, citric acid, glycine, histidine, latex, polysorbate, mannitol, methionine, papain, sodium acetate, sodium chloride, sodium citrate, sodium phosphate, sorbitol, trehalose, trometamol, and sucrose ([35, 53]; Table 7). Polysorbates, emulgators and stabilizers of the active ingredients of BSs, can cause HSRs by activating the comple- ment system. In addition, as a result of degradation of polysorbates, A. oxidation of the mAb may occur, thereby increasing its immunogenicity; B. a number of reactive products may develop, functioning as haptens, interacting with proteins at the injection site, followed by ISRs [54]. Many drugs and BSs that we use in our daily clinical practice contain polysorbate. However, in a recently published case report, polysorbate was shown to be the cause of anaphylaxis the patient had developed to corticosteroids [55]. In addition, syringe needle protectors of some BSs such as adalimumab, etanercept, and anakinra contain latex, so that they may be responsible for some reactions ([35]; Table 8).

The importance of these other substances for the allergic reactions is not yet fully understood and further research is needed. Detailed information about
Fig. 3 Algorithm for the management of hypersensitivity reactions. (BP blood pressure, $H R$ heart rate, $T$ temperature, SBP systolic blood pressure, SpO2 peripheral oxygen saturation, IM intramuscular, i.v. intravenous, $P O$ per os, ASA acetylsalicylic acid. Adapted from Galvão et al. [40] with permission)

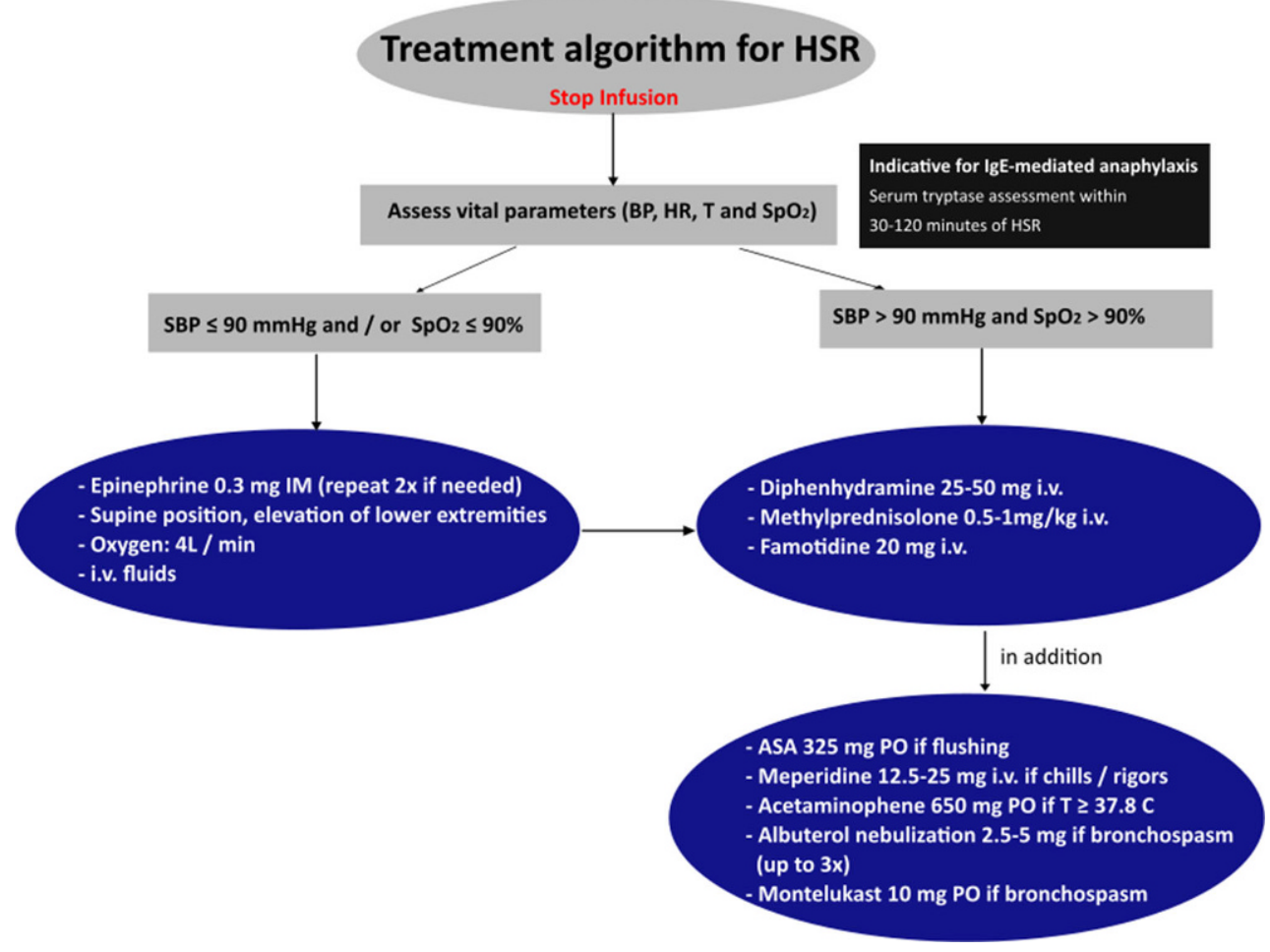


Table 10 An example of desensitization protocols: rituximab i.v. $\quad\left(\right.$ Ritux ${ }^{\circledR}$ $851 \mathrm{mg}$ ), solution preparation [76]

\begin{tabular}{|c|c|c|c|}
\hline Bags & $\begin{array}{l}\text { Volume } \\
(\mathrm{mL})\end{array}$ & $\begin{array}{l}\text { Concentration } \\
(\mathrm{mg} / \mathrm{mL})\end{array}$ & Total amount of drug per solution (mg) \\
\hline Solution 1 & 250 & 0.034 & 8.51 \\
\hline Solution 2 & 250 & 0.34 & 85 \\
\hline Solution 3 & 250 & 3.40 & 851 \\
\hline
\end{tabular}

the components of BSs and potentially allergenic excipients is given in Tables 7 and 8 .

\section{Basophil activation test}

Basophils play an important role in allergic reactions and diseases by releasing their own mediators.

Studies in the last 15 years have reported that the BAT is useful in the diagnosis of allergic reactions to various drugs (betalactams, quinolones, H2 blockers, neuromuscular blocking agents), foods (egg, milk, peanut), venoms (bee, wasp), and pollens (birch, timothy grass), and D. pteronyssinus (referenced in [56]).

Piva et al. [57] investigated the importance of the basophil activation test (BAT) in five patients with an anaphylactic reaction (angioedema, bronchospasm, hypotension, and urticaria) to rituximab. In this study, the percentage of CD63 expression in basophils was reported to be higher than in healthy controls. Therefore, it was emphasized that BAT (using CD63 as measurement for their activation status) may be helpful in cases with HSR against rituximab, when standard diagnostic tests are not available and diagnosis is difficult [57]. In addition, Iwamoto et al. [58] emphasized that further advanced tests targeting the interactions and bindings of IgE-cetuximab on basophils can be useful in predicting severe HSRs for cetuximab. BATs using CD63 and/or CD203c to measure basophil activation have been reported to be a fast and reliable test with diagnostic benefits in patients that develop life-threatening anaphylaxis induced by various drugs [59]. Further large scale studies with various BSs are needed to establish the BAT as a diagnostic tool for this entity.

\section{Management of reactions to biotechnological substances}

Today, the use and indications of biological treatments in different medical fields continue to increase. Therefore, the management of drug-related reactions has become important for the sustainability of treatment and safety for patients in daily practice. Algorithmic approaches should be developed and optimized to identify patients potentially at risk and in order to minimize the risk beforehand. Loss of immune tolerance causes problems such as the development of cancers and susceptibility to infections in some patients.

The risk for the development of HSRs to BSs depends on several factors: The degree of humanization of BSs, the additional ingredients, the type of adminis- tration (intravenous, subcutaneous, and intramuscular), the treatment intervals (and treatment pauses), the development of ADAs, and the clinical characteristics of the patients.

\section{Premedication/concomitant medication/prophylaxis}

There is still controversial data regarding the administration of premedication before treatment with BSs [14]. However, premedication for potential IRs and HSRs is recommended in FDA labels of many intravenously administered BSs. Low infusion rate, avoidance of long intervals between infusions and pretreatment with antihistamine and prednisone may prevent immediate and avoid delayed reactions [60]. In addition, $\mathrm{H} 1$ antihistamines plus acetaminophen or high-dose corticosteroid administration is recommended as prophylaxis for CRS induced by mAbs used in some cancer treatments and can significantly reduce the incidence and severity of CRS [61]. In rheumatoid arthritis patients, it has been reported that combination therapy with an anti-TNF- $\alpha$ and methotrexate reduces the development of ADA, thereby reducing the neutralization of the drug and reducing the risk of immunological reactions [17, 18, 62]. Further research is needed on the use of concomitant drugs with BSs. The literature describes desensitization protocols to reduce the risk of anaphylactic reactions to BSs, for example, for adalimumab [63]. In addition, adalimumab is the treatment alternative for patients with severe anaphylactic reactions to infliximab, another anti-TNF- $\alpha$ mAb [64].

\section{Acute infusion reactions}

An example approach in infusion centers according to the severity of acute infusion reactions is given in Table 9; [65, 66]. The management of acute infusion reactions is generally achieved by premedication with antihistamines, analgesics, corticosteroids, and slowing infusion rates $[15,65,66]$.

\section{Prevention of acute hypersensitivity reactions}

Galvao et al. proposed an algorithmic treatment approach for HSRs [40]. This recommends treatment according to the vital parameters of the patients after the reaction, and offers treatment options for subsequent reactions (Fig. 3; [40]).

\section{Desensitization protocols}

Rapid drug desensitization (RDD) is a highly important treatment option that may protect patients from 


\begin{tabular}{|c|c|c|c|c|c|c|}
\hline Step & Solution & Rate $(\mathrm{mL} / \mathrm{h})$ & Time (min) & $\begin{array}{l}\text { Volume infused per } \\
\text { step }(\mathrm{mL})\end{array}$ & Administered dose (mg) & Cumulative dose (mg) \\
\hline 1 & 1 & 2 & 15 & 0.5 & 0.017 & 0.017 \\
\hline 2 & 1 & 5 & 15 & 1.25 & 0.042 & 0.059 \\
\hline 3 & 1 & 10 & 15 & 2.5 & 0.085 & 0.145 \\
\hline 4 & 1 & 20 & 15 & 5 & 0.17 & 0.315 \\
\hline 5 & 2 & 5 & 15 & 1.25 & 0.42 & 0.740 \\
\hline 6 & 2 & 10 & 15 & 2.5 & 0.85 & 1.59 \\
\hline 7 & 2 & 20 & 15 & 5 & 1.70 & 3.29 \\
\hline 8 & 2 & 40 & 15 & 10 & 3.40 & 6.69 \\
\hline 9 & 3 & 10 & 15 & 2.5 & 8.51 & 15.20 \\
\hline 10 & 3 & 20 & 15 & 5 & 17.0 & 32.23 \\
\hline 11 & 3 & 40 & 15 & 10 & 34.0 & 66.27 \\
\hline 12 & 3 & 80 & 172.89 & 230.53 & 784.732 & 851.000 \\
\hline
\end{tabular}

severe reactions and anaphylaxis and ensures that their treatment continues. However, this treatment option is absolutely contraindicated in delayed onset cases such as toxic epidermal necrolysis, StevensJohnson syndrome, serum sickness, exfoliative or bullous dermatitis, acute generalized exanthematous pustulosis, erythema multiforme, vasculitis, and systemic drug reactions with eosinophilia $[14,40]$. There are different approaches for RDD in various centers, and the protocols are not fully standardized and harmonized for the BSs.

There are many BSs (such as adalimumab, alemtuzumab, anakinra, bevacizumab, brentuximab, cetuximab, etanercept, infliximab, nivolumab, ofatumumab, panitumumab, rituximab, tocilizumab, and trastuzumab) in which RDD has been successfully applied, and new ones are added to the literature on a daily basis [40,67-75]. An example for the 12-step RDD with rituximab is given in Tables 10 and 11 (for calculation see Ref. [76]). If any reaction occurs during RDD, the infusion and the application should be stopped. Additional medications should be administered according to the clinical condition observed in the patient.

The 12-step RDD protocol developed at Brigham and Women's Hospital (BWH; Boston, MA, USA) has been recognized worldwide $[77,78]$. In general, the standard RDD protocol includes a three-step process. This includes three 250-mL solutions with 10 -fold increasing concentrations and a total of 12 steps in which the dose is doubled every $15 \mathrm{~min}$ by increasing speed and/or concentration [40, 76, 79]. The treatment dose starts at a dilution of $1 / 1000$ to $1 / 10,000$. The first bag and second bag contain a 1/100 and a $1 / 10$ dilution solution, respectively [40]. The third bag is calculated by subtracting the cumulative dose from steps 1 to 8 from the targeted dose, and is administered over a relatively long period of time compared to the first two steps (calculation in Ref.[76]). There are also 16-step protocols in the literature, which are used for patients with severe anaphylactic reactions such as cardiac arrest [78].

Brown et al. classified acute systemic HSRs with a simpler and more useful grading system [80]. Accordingly, reactions are divided into three groups.

- Grade 1: Only cutaneous reactions

- Grade 2: Reactions involving symptoms of the respiratory, cardiovascular system, or gastrointestinal tract

- Grade 3: Loss of consciousness, hypoxia or hypotension, and cardiovascular collapse

Some experienced centers desensitize 3rd degree reactions according to this classification in the intensive care unit [33]. Patients that tolerate the first desensitization and those with 1-2 degree reactions receive desensitization treatments in outpatient infusion centers.

\section{Conclusion}

HSRs to BS are gradually increasing with the widening of clinical use and indications. It is very important to prevent HSRs, to know the degree of severity and the emergency treatment algorithm, as well as to apply desensitization when necessary. In this review, the authors have sought to extract information from the literature containing all these issues and provide some structures that help to classify the reactions that may have occurred in their daily practice. They have summarized the diagnostic tests that should be applied: (a) immediately during/after a reaction, and (b) subsequently, and in the case that a switch of BS is not possible, desensitization is an option.

Acknowledgements Funding of the Federal Ministry for Science and Education (BMBF), German Center for Lung Research, is gratefully acknowledged.

Author Contribution AG: Data collection, design of tables and figures, analysis and interpretation of data, writing and 
drafting of the manuscript; BW: major role in revising the manuscript; UJ: concept of the manuscript, acquisition of data, design of Fig. 1, writing and revising the manuscript.

Funding Open Access funding provided by Projekt DEAL.

Conflict of interest A. Gülsen, B. Wedi, and U. Jappe declare that they have no competing interests.

Open Access This article is licensed under a Creative Commons Attribution 4.0 International License, which permits use, sharing, adaptation, distribution and reproduction in any medium or format, as long as you give appropriate credit to the original author(s) and the source, provide a link to the Creative Commons licence, and indicate if changes were made. The images or other third party material in this article are included in the article's Creative Commons licence, unless indicated otherwise in a credit line to the material. If material is not included in the article's Creative Commons licence and your intended use is not permitted by statutory regulation or exceeds the permitted use, you will need to obtain permission directly from the copyright holder. To view a copy of this licence, visit http://creativecommons.org/licenses/by/4.0/.

\section{References}

1. Scherer K, Spoerl D, Bircher AJ. Adverse drug reactions to biologics. J Dtsch Dermatol Ges. 2010;8(6):411-26.

2. Vultaggio A, Petroni G, Pratesi S, Nencini F, Cammelli D, Ferraro A, et al. How the immune system responds to therapeutic biological agents. J Int Med Res. 2016;44:38-42.

3. Flood-Page P, Swenson C, Faiferman I, Matthews J, Williams M, Brannick L, et al. A study to evaluate safety and efficacy of mepolizumab in patients with moderate persistent asthma. Am J Respir CritCare Med. 2007;176:1062-71.

4. Ferrer M, Madamba R. Biologics in chronic urticaria. Allergol Immunopathol (Madr). 2017;45:41-4.

5. Kawalec P, Holko P, Moćko P, Pilc A. Comparative effectiveness of abatacept, apremilast, secukinumab and ustekinumab treatment of psoriatic arthritis: a systematic review and network meta-analysis. Rheumatol Int. 2018;38:189-201.

6. World Health Organization. International Nonproprietary Names (INN) for biological and biotechnological substances. (A review) 2019. https:/ / www.who.int/medicines / services/inn/BioReview2019.pdf?ua=1. Accessed $28 \mathrm{Apr}$ 2020.

7. American Medical Association. Monoclonal antibodies. 2019. https://www.ama-assn.org/about/united-statesadopted-names/monoclonal-antibodies. Accessed 04 May2020.

8. Jappe U. Allergic reactions to oncology biologics. AllergoOncology Section of EAACI Congress; Munich. 2018.

9. Casale TB. Biologics and biomarkers for asthma, urticaria, and nasal polyposis. J Allergy Clin Immunol. 2017;139:1411-21.

10. PichlerWJ.Adverseside-effects to biological agents. Allergy. 2006;61:912-20.

11. Barbaud A, Granel F, Waton J, Poreaux C. How to manage hypersensitivity reactions to biological agents? Eur J Dermatol. 2011;21:667-74.

12. Shimabukuro-Vornhagen A, Gödel P, Subklewe M, Stemmler HJ, Schlößer HA, Schlaak M, et al. Cytokine release syndrome. JImmunother Cancer. 2018;6(1):56.

13. Suntharalingam G, Perry MR, Ward S, Brett SJ, CastelloCortes A, Brunner MD, et al. Cytokine storm in a phase 1 trial of the anti-CD28 monoclonal antibody TGN1412. N Engl J Med. 2006;355:1018.

14. Vultaggio A, Castells MC. Hypersensitivity reactions to biologic agents. Immunol Allergy Clin North Am. 2014;34:615-32.

15. Chung $\mathrm{CH}$. Managing premedications and the risk for reactions to infusional monoclonal antibody therapy. Oncologist. 2008;13:725-32.

16. Boven K, Knight J, Bader F, Rossert J, Eckardt KU, Casadevall N. Epoetin-associated pure red cell aplasia in patients with chronic kidney disease: solving the mystery. Nephrol Dial Transplant. 2005;20(Suppl 3):iii33-40. Erratum in: NephrolDial Transplant. 2006;21:2678.

17. Pascual-SalcedoD, PlasenciaC, RamiroS, NuñoL, BonillaG, Nagore D, et al. Influence of immunogenicity on the efficacy of long-term treatment with infliximab in rheumatoid arthritis. Rheumatology. 2011;50:1445-52.

18. Atiqi S, Hooijberg F, Loeff FC, Rispens T, Wolbink GJ. Immunogenicity of TNF-Inhibitors. Front Immunol. 2020;11:312.

19. Maggi E, Vultaggio A, Matucci A. Acute infusion reactions induced by monoclonal antibody therapy. Expert Rev Clin Immunol. 2011;7:55-63.

20. Benucci M, Grossi V, Manfredi M, Damiani A, Infantino M, et al. Laboratory Monitoring of Biological Therapies in Rheumatology: The Role of Immunogenicity. Ann Lab Med 2020;40(2):101-13.

21. Ramos-Casals $M$, Brito-Zerón $P$, Muñoz S, Soria N, Galiana D, Bertolaccini L, et al. Autoimmune diseases induced by TNF-targeted therapies: analysis of 233 cases. Medicine (Baltimore). 2007;86:242-51.

22. Lenz HJ. Management and preparedness for infusion and hypersensitivity reactions. Oncologist. 2007;12:601-9.

23. Gell PGH, Coombs RRA. The classification of allergic reactions underlying disease. In: Coombs RRA, Gell PGH, editors. Clinical aspects of immunology. Oxford: Blackwell Science; 1963. pp.317-37.

24. Uzzaman A, Cho SH. Chapter 28: Classification of hypersensitivity reactions. Allergy Asthma Proc. 2012;33:96-9.

25. Ring J, Messmer K. Incidence and severity of anaphylactoid reactions to colloid volume substitutes. Lancet. 1977;1(8009):466-9.

26. Ring J, Beyer K, Biedermann T, Bircher A, Duda D, Fischer J et al. Guideline for acute therapy and management of anaphylaxis. S2 guideline of DGAKI, AeDA, GPA, DAAU, BVKJ, ÖGAI, SGAI, DGAI, DGP, DGPM, AGATE and DAAB. Allergo J Int 2014; 23: 96-112.

27. Banchereau J, Pascual V, Palucka AK. Autoimmunity through cytokine-induced dendritic cell activation. Immunity. 2004;20:539-50.

28. Peréz-SolerR,SaltzL.CutaneousadverseeffectswithHER1/ EGFR-targeted agents: Is there a silver lining? J Clin Oncol. 2005;23:5235-46.

29. Weng MS, Chang JH, Hung WY, Yang YC, Chien MH. The interplay of reactive oxygen species and the epidermal growth factor receptor in tumor progression and drug resistance. J Exp Clin Cancer Res. 2018;37:61.

30. Sinagra E, Perricone G, Romano C, Cottone M. Heart failure and anti tumor necrosis factor-alpha in systemic chronic inflammatory diseases. Eur J Intern Med. 2013;24:385-92.

31. Al-Huthail YR. Neuropsychiatric side-effects of interferon alfa therapy for hepatitis $C$ and their management: a review. SaudiJ Gastroenterol. 2006;12:59-67.

32. Mathur G, Singh DV, Singal A. Unusual course of interferon-related retinopathy in chronic hepatitis C. Oman J Ophthalmol. 2016;9:189-90. 
33. Hsu Blatman KS, Castells MC. Desensitizations for chemotherapy and monoclonal antibodies: indications and outcomes. Curr Allergy Asthma Rep. 2014;14:453.

34. Isabwe GAC, de Las Vecillas Sanchez L, Castells M. Management of adverse reactions to biologic agents. Allergy Asthma Proc. 2017;38:409-18.

35. Corominas M, Gastaminza G, Lobera T. Hypersensitivity reactions to biological drugs. J Investig Allergol Clin Immunol. 2014;24:212-25.

36. Picard M, Galvão VR. Current Knowledge and Management of Hypersensitivity Reactions to Monoclonal Antibodies. J Allergy Clin Immunol Pract. 2017;5(3):600-9.

37. Castells M. Drughypersensitivity and anaphylaxis in cancer and chronic inflammatory diseases: the role of desensitizations. Front Immunol. 2017;8:1472.

38. Cox L, Lieberman P, Wallace D, Simons FE, Finegold I, Platts-Mills T, et al. American Academy of Allergy, Asthma \& Immunology/American College of Allergy, Asthma \& Immunology Omalizumab-Associated Anaphylaxis Joint Task Force follow-up report. J Allergy Clin Immunol. 2011;128:210-2.

39. Lieberman P, Rahmaoui A, Wong DA. The safety and interpretability of skin tests with omalizumab. Ann Allergy Asthma Immunol. 2010;105:493-5.

40. Galvão VR, Castells MC. Hypersensitivity to biological agents-updated diagnosis, management, and treatment. JAllergy Clin Immunol Pract. 2015;3:175-85.

41. Aberer W, Bircher A, Romano A, Blanca M, Campi P, Fernandez J. European Network for Drug Allergy (ENDA); EAACI interest group on drug hypersensitivity. Drug provocation testing in the diagnosis of drug hypersensitivity reactions: general considerations. Allergy. 2003;58(9):854-63.

42. Vultaggio A, Matucci A, Nencini F, Pratesi S, Parronchi P, Rossi O, et al. Anti-infliximab IgE and non-IgE antibodies and induction of infusion-related severe anaphylactic reactions. Allergy. 2010;65:657-61.

43. Vultaggio A, Matucci A, Nencini F, Pratesi S, Maggi E. Skin testing and infliximab-specific antibodies detection as a combined strategy for preventing infusion reaction. Intern Emerg Med. 2012;7:77-9.

44. Cazzola M, Matera MG, Levi-Schaffer F, Rogliani P. Safety of humanized monoclonal antibodies against IL-5 in asthma: focus on reslizumab. Expert Opin Drug Saf. 2018;17:429-35.

45. Matucci A, Nencini F, Pratesi S, Maggi E, Vultaggio A. An overview on safety of monoclonal antibodies. Curr Opin Allergy Clin Immunol. 2016;16:576-81.

46. Homann A, Röckendorf N, Kromminga A, Frey A, Jappe U. B cell epitopes on infliximab identified by oligopeptide microarray with unprocessed patient sera. J Transl Med. 2015;13:339.

47. Homann A, Röckendorf N, Kromminga A, Frey A, Platts-Mills T, Jappe U. Distinct glycan and peptide IgE epitopes of the TNF-alpha blockers infliximab and adalimumab-precision diagnostics by cross-reactivity immune profiling of patient sera. Theranostics. 2017;7:4699-709.

48. Steenholdt C, Svenson M, Bendtzen K, Thomsen OØ, Brynskov J, Ainsworth MA. Acute and delayed hypersensitivity reactions to infliximab and adalimumab in a patient with Crohn's disease. JCrohns Colitis. 2012;6:108-11.

49. Somerville L, Bardelas J, Viegas A, D'Andrea P, Blogg M, Peachey G. Immunogenicity and safety of omalizumab in pre-filled syringes in patients with allergic (IgE-mediated) asthma. Curr Med Res Opin. 2014;30:59-66.

50. Baker DL, Nakamura GR, Lowman HB, Fischer SK. Evaluation of IgEantibodies to omalizumab (Xolair ${ }^{\circledR}$ ) and their potential correlation to anaphylaxis. AAPS J. 2016;18:115-23.
51. Chung CH, Mirakhur B, Chan E, Le QT, Berlin J, Morse M, et al. Cetuximab-induced anaphylaxis and IgE specific for galactose-alpha-1,3-galactose. N Engl J Med. 2008;358:1109-17.

52. Jappe U, Minge S, Kreft B, Ludwig A, Przybilla B, Walker A, et al. Meat allergy associated with galactosyl- $\alpha-(1,3)$ galactose $(\alpha-\mathrm{Gal})$ - closing diagnostic gaps by anti- $\alpha-\mathrm{Gal}$ IgEimmune profiling. Allergy. 2018;73:93-105.

53. Joshi SR, Khan DA. Anaphylaxis induced by biologics. Curr Treat Options Allergy. 2019;6:125-41.

54. Singh SK, Mahler HC, Hartman C, Stark CA. Are injection site reactions in monoclonal antibody therapies caused by polysorbate excipient degradants? J Pharm Sci. 2018;107(11):2735-41.

55. Palacios Castaño MI, Venturini Díaz M, Lobera Labairu T, González Mahave I, Del Pozo Gil MD, et al. Anaphylaxis due to the excipient polysorbate 80 . J Investig Allergol Clin Immunol. 2016;26(6):394-6.

56. Hemmings O, Kwok M, McKendry R, Santos AF. Basophil activation test: old and new applications in allergy. Curr AllergyAsthma Rep. 2019;19(12):58.

57. Piva E, Chieco-Bianchi F, Krajcar V, Aversa S, Plebani M. Adverse reactions in patients with B-cellymphomas during combined treatment with rituximab: in vitro evaluation of rituximab hypersensitivity by basophil activation test. Am J Hematol. 2012;87:130-1.

58. Iwamoto T, Okamoto A, Ishinaga H, Shimizu K, Gayle AA, Takeuchi K, et al. A novel approach to predict cetuximab-induced hypersensitivity reaction: detection of drug-specific IgE on basophils. Cancer Med. 2016;5(6):1004-12.

59. Kim SY, Kim JH, Jang YS, Choi JH, Park S, Hwang YI, et al. The basophil activation test is safe and useful for confirming drug-induced anaphylaxis. Allergy Asthma Immunol Res. 2016;8(6):541-4.

60. Vultaggio A, Matucci A, Parronchi P, Rossi O, Palandri F, RomagnaniS, etal. Safety and tolerability ofinfliximab therapy: suggestions and criticisms based on wide clinical experience. Int Jmmunopathol Pharmacol. 2008;21:367-74.

61. Vogel WH. Infusion reactions: diagnosis, assessment and management. Clin J Oncol Nurs. 2010;14:10-21.

62. Matucci A, Cammelli D, Cantini F, Goletti D, Marino V, Milano GM, et al. Influence of anti-TNFimmunogenicity on safety in rheumatic disease: a narrative review. Expert Opin Drug Saf. 2016;15:3-10.

63. Quercia O, Emiliani F, Foschi FG, Stefanini GF. Adalimumab desensitization after anaphylactic reaction. Ann Allergy Asthma Immunol. 2011;106:547-8.

64. Stallmach A, Giese T, Schmidt C, Meuer SC, Zeuzem SS. Severe anaphylactic reaction to infliximab: successful treatment with adalimumab-report of a case. Eur J Gastroenterol Hepatol. 2004;16:627-30.

65. Moss IB, Moss MB, dos Reis DS, Coelho RM. Immediate infusional reactions to intravenous immunobiological agents for the treatment of autoimmune diseases: experience of 2126 procedures in a non-oncologic infusion centre. Rev Bras Reumatol. 2014;54:102-9.

66. National Institutes of Health National Cancer Institute. Common Terminology Criteria for Adverse Events (CTCAE). Version 5.0. 2017. https://ctep.cancer.gov/ protocolDevelopment/electronic_applications/docs/ CTCAE_v5_Quick_Reference_5x7.pdf. Accessed 25 Aug 2019.

67. MersinSS, BulutI, YakutT, Örçen C, TepetamFM. Successful desensitization with panitumumab; a case report. Allergy. 2019;74:741-2

68. Soyyiğit Ş, Kendirlinan R, Aydın O, Çelik GE. Successful desensitization with anakinra in a case with immediate 
hypersensitivity reaction. Ann Allergy Asthma Immunol. 2014;113(3):325-6.

69. Gutiérrez-Fernández D, Saldaña-Valderas M, de la VargaMartínez R, Foncubierta-Fernández A, Fernández-Anguita MJ, Fernández-Valle MDC, et al. Hypersensitivity to alemtuzumab. A safe and effective desensitization protocol: a case report. JOncol Pharm Pract. 2019;25:1016-20.

70. Williams SJ, Khokhar A, Gharib A. Successful rapid desensitization to intravenous bevacizumab using a 14-step protocol: case report. J Allergy Clin Immunol Pract. 2017;5:1746-7.

71. Di Girolamo A, Albanesi M, Sinisi A, Nettis E, Di Bona D, Caiaffa MF, et al. Rapid desensitization for brentuximab vedotin (Adceteris ${ }^{\circledR}$ ) allergy: a case report. Clin Mol Allergy. 2018;16:22.

72. Giavina-Bianchi P, Aun MV, GalvãoVR, Castells M. Rapid desensitization in immediate hypersensitivity reaction. Curr Treat Options Allergy. 2015;2:268-85.

73. Cortellini G, Mascella F, Simoncelli M, Lippolis D, Focherini MC, Cortellini F, et al. Effective desensitization to tocilizumab in delayed hypersensitivity reaction. Pharmacology. 2018;102:114-6.
74. Wang CS, Liverman RS, Garro R, George RP, Glumova A, Karp A, et al. Ofatumumab for the treatment of childhood nephrotic syndrome. Pediatr Nephrol. 2017;32:835-41.

75. Sáenz de Santa María García M, Noguerado-Mellado B, Rojas-Pérez-Ezquerra P, Prieto-García A, Bartolomé-Zavala B, Tornero P. First case of allergy to nivolumab. J Allergy Clin Immunol Pract. 2017;5(4):1140-1.

76. HemOnc.org - A Free Hematology/Oncology Reference. Rituximab (Rituxan) desensitization protocol. https://hemonc.org/wiki/Rituximab_(Rituxan)_ desensitization_protocol and https://hemonc.org/w/ images/2/2f/Ritixumab_desensitization_spreadsheet.xls. Accessed 30 Apr 2020.

77. Castells M. Rapid desensitization for hypersensitivity reactions to medications. Immunol Allergy Clin North Am. 2009;29:585-606.

78. Castells M. Drug desensitization in oncology: chemotherapy agents and monoclonal antibodies. In: Pichler WJ, editor. Drughypersensitivity. Basel: Karger;2007.pp. 413-25.

79. Khan DA. Hypersensitivity and immunologic reactions to biologics: opportunities for the allergist. Ann Allergy Asthma Immunol. 2016;117:115-20.

80. Brown SG. Clinical features and severity grading of anaphylaxis. JAllergy Clin Immunol. 2004;114:371-6. 